\title{
Teaching of Telecommunication-Specific University Course in Cooperation with Partners from Industry
}

\author{
A. Ainomae, I. Rokk, E. Lossmann \\ Department of Radio and Communication Engineering, Tallinn University of Technology, \\ Ehitajate tee 5, 19086 Tallinn, Estonia, phone: +372620 2369, e-mail: indrek@lr.ttu.ee
}

\section{Introduction}

In modern information and telecommunication technology market the technology is rapidly evolving in time with new different technology concepts developed every day. Industry needs skilled employees who have understanding and knowledge of said technologies so they can deploy them in working environment. Universities, especially universities of applied science (UAS), need this technology transfer in order to keep their curricula's current and up to date with industry needs and to expose students to the emerging technological trends. Students will be supplied with up-to date and as well right kind of skills with this co-operation.

One example of such rapidly evolving area for telecommunication industry is Value Added Services (VAS) and IP Multimedia Subsystem (IMS). VAS is a telecommunications industry term for non-core services to add a value for standard voice and video transmission services for promoting the usage of these standard services. Operators can develop their specific VAS services and that way differentiate in the market. IMS is a standardized Next Generation Network architecture for an Internet mediaservices (Internet Protocol based) capability, defined by the European Telecommunications Standards Institute (ETSI) and the 3rd Generation Partnership Project (3GPP). Instead of standardizing applications, IMS aims to define the access of multimedia and voice applications from wireless and wireline terminals.

There are many articles written about industry science relationship and knowledge transfer from academia to industry, but not much in opposite direction. In article [1] is presented different categories and forms of relationships between industry and academia. On of the forms is mobility of people and in mobility from industry to public knowledge institutes. In article [2] is shown that one role what industry can have is to be teacher i.e. the experts are invited to academia to share their expertise with students.

In this paper we present our experiences and observations on teaching of course, where teachers and knowledge come from industry. Course "I364 IMS Overview" has been taught in Estonian IT College (EITC) for 3 years. The majority of the students come from two curricula (total number -4 curricula) with larger number of students - IT Systems Development and IT Systems Administration. In last two years the course is also offered for Tallinn University of Technology (TUT) telecommunication master students as a part of one existing masters study course. The course is elective in both universities and therefore students have different knowledge and experience level in programming (Java programming language and software development environments like Eclipse), IP networks (network structures, traffic models, protocols, standards) and in the concept of VAS (structure, traffic models, session and media control).

Course capacity is 3 ECTS credits and teaching methods include weekly lectures ( 2 academic hours per week) and seminars/laboratory exercises (2 academic hours per week), total 8 weeks/semester. Lectures are video recorded and made available for students, unless presenter asks not to do so due to sensitive information. Recordings allow students review lectures. Course assessment is final test based on the laboratory work. Course is taught in second half of autumn semester.

On first year 9 EITC students took and passed the course. On second year 19 EITC and 13 TUT students took course, only one EITC student failed the course. On the third year the sign-up numbers were respectively 24 EITC and 6 TUT students, from which 2 EITC students failed the course. Reason for course failure is that student sign-up for the course, but don't show up for the course.

At the end of the course feedback is gathered from students through EITC course feedback system. At the time of writing the paper, feedback for the last course in the EITC course feedback system wasn't available. Adjustments to the course are done according to feedback.

\section{Designing the course and lectures}

The main driving force from some industry partners to introduce the course to the university is to teach students 
basic concepts behind technology so that they can start developing applications on their own.

In the designing phase of the course with industry partners were agreed that teaching in lectures and laboratory exercises is done by industry partner employees and other experts in the subject. University set academic guidelines and requirements what need to be met in order to teach course in the university. This requirement can be summarized with - in the context of teaching the academics define the general contents of a curriculum. The industry partner then has to be able to deliver the contents using their experience [3].

Industry representatives who were lecturing in the course had all strong technical background and good knowledge in the subject. Besides positive sides, it had some negative side effects. More precisely some presenters were good experts, but didn't have strong presentation skills to teach their subject. Depending from the case we either gave them a short course on presentation or found some other alternatives in terms of additional lecturers.

From students feedback and observations from lectures we have discovered that as lecturers have deep knowledge on the field they sometimes tend to expect the same from the audience the same thing. Therefore they assume too much from audience and slid over too fast from basic concepts. Also they tend to use too much acronyms so that students feel lost.

There is also need for good synchronization between lecturers in order to avoid unnecessary repetition of lecture topics or to avoid situation where some topics are left out due to fact that lecturer assumes that other will talk about it. This is the work of university side coordinator whose task is to synchronize lecture topics between lecturers. One thing that helps is that coordinator sends short overview with key topics of the lecture to following lecturer so he or she can take into account previous lectures.

In some cases we have observed that if lecturer is giving same lecture in many years and use the same slides then their lectures tend to shorten as to them seems that they have told things repeatedly and therefore slide over some lesser topics in the lecture.

\section{Seminars and laboratory exercises}

The main task for developing the lab exercises for the course has been to find a good compromise between the students entry level knowledge and background required for enrolling to the class. On the other hand the need to cover the number of main topics in sufficient level for introducing the VAS development and implementation using IMS structure and service development tools.

The course focus has been on the seminars and labs. Students have had to participate in the seminars and solve the 6 laboratory exercises. In addition to the lab works, master students have been asked to present an independent research work on pre-selected topics about IMS solutions, VoIP, SIP and RTP based communications. One full time seminar has been reserved to present and defend the research work.

The structure of the seminars and laboratory exercises has been divided into the following main parts.
Introduction to SIP protocol. Within this laboratory session the main and common SIP session traffic cases are studied - the usage of the different SIP methods, supported by the protocol. Also it covers the traffic routing (both endto-end and hop-by-hop) between different network nodes in the IMS network. Students have had to design the SIP traffic flows, based on the different use case by solving 5 main exercises. Exercises are done in Excel spreadsheets, as this allows easily write data into SIP messages headers. Two full time seminars have been planned for this section and it has been lead by the specialists who has deep knowledge in the field as he has been worked extensively in developing and testing of IMS and SIP related products to industry partners.

Introduction to IMS and VAS architecture. First year of teaching has shown that students have weak background in order to understand the concept of VAS. Therefore we have reserved a full seminar to give an introduction about VAS and IMS architecture and about other major generic concepts in this field. The seminar form instead of a lecture has been chosen on purpose to keep closer contact with students for interactivity. The seminar and the following laboratory works have been held by specialists from Ericsson Estonia together with an instructor form EITC.

The seminar itself has been divided into following parts. Communication Media - Telecom Network types and main service types in these networks. This part shortly recalls the OSI architecture and shows the location of main known transport and higher layer communication protocols. Shortly the IP network routing and network socket concept in network interfaces programming has been covered.

We have found that starting directly from introducing IMS architecture and Next Generation Network standards will not give a clear and sufficient overview for the students if some experience in the field is missing. We suggest that the architectural view and main concepts need to be introduced before we let students to work with the simulations in service development environments. Therefore the VAS concept introduction has been done based on historical path of technology evolution - starting with explanation of classical Intelligent Networks (IN). That way covering main communication protocols (SS7 and main IN network nodes) and showing the main traffic flows on the board. The drawings have been presented on the board on purpose for students being able to follow the evolution in terms of layer additions and extensions to the telecom network operator core layer. That way introduction to Parlay specification (due to the usage of CORBA, also slight introduction to the concept of distributed computing) has been done and the methods of connecting internet services to classical closed telecom networks have been shown. The technology evolution has been illustrated with main type of services provided today by telecom network operators by showing the main traffic cases on the drawn network structure pictures. The difference between the call session control traffic and physical media traffic has been explained.

After completing the explanation of the VAS concept, we feel that it is much easier to move over to introduction of IMS certification, while students have already got an overview about the idea of VAS. The IMS standardization 
history overview (standardization requirements and the system design base) has been explained. Main protocols in the standardization are shown and main functions of the main nodes in the IMS architecture are explained. Here we have limited the focus on selected IMS network nodes to standardized main components: 3 types of CSCF, application server and DNS.

We have made a selection of the protocols and are focusing the attention to SIP and RTP, with reviewing SIP concept. Here we have focused more on the telecommunication aspect of the protocols by showing the SIP protocol stack layers, different transport protocol usage for carrying SIP traffic and also we have given an overview about main SIP operations used in a session control. NAT problem in routing SIP traffic in IP networks have been covered.

The fourth part of this seminar has been prepared mainly for the master students of telecommunication program and is covering the basics of media (audio and video) processing and transmission over IP networks. The definition of a codec, the widely used coders and the problems related to channel bandwidth are introduced. RTP protocol for transmitting media information and RTP transmission in IP network is handled.

This seminar is taking a short look into different concepts, standards and traffic models, but we believe it is necessary to create an understanding for students to continue with the next lab exercises.

The slides have been represented in English for giving students an overview about the English terminology, as there is deficit of Estonian terminology.

Introduction to the IMS development and testing platform. At the moment the platform was Ericsson's IMS service development and testing platform called SDS (Service Development Studio). It is based on an Eclipse and provides a simulated IMS environment for being able to develop a service in Java, run the main functions of IMS environment (DNS, P-CSCF, S-CSCF, Application Server) and to be able to run the developed application, analyze the main SIP traffic flows and troubleshoot the problems. This seminar is also covering shortly some aspects in software development models and processes.

It has to be noted that licensing of the SDS software has been changed over the years. Initially the software was freely downloadable on Ericsson's website from Ericsson's developer program page. For the third year of the course, Ericsson had changed the licensing strategy and free SDS download option was discontinued. Therefore additional negotiations were needed to get the acceptance for the usage of the software for the course.

Practical usage of SDS. In the fourth laboratory exercise we have decided to let students first to get an experience with Eclipse based SDS just by importing an example application from Ericsson into the simulated system. Students are importing the needed application code parts into the simulated application server container, then they find out and build the IMS service environment, start the system and run simulated test calls. Students have also got a task to analyze the generated SIP flows and take notes for next labs. Since the system is run on a local computer of a laboratory computer, the network packet analyzers can't be used in this phase.
Troubleshooting non-working application. The fifth lab exercise has been designed for letting students to troubleshoot a non-working application and environment by finding out the faults, correcting them to get the system working. During the first year of the course, the task was to write an own application in Java, to implement it to simulated system and generate the traffic. Students got requirements and small pre-written code for further development. The developed application architecture was based on an example application structure, present in the SDS environment and only some small function changes in the application logic were expected. Still, since the students experience with Java development was different, we decided to introduce the changes in the task of troubleshooting exercise in the $2^{\text {nd }}$ year as this doesn't require Java development skills.

For successful troubleshooting students have to have good understating of the concepts and system design. Therefore from the $2^{\text {nd }}$ year of teaching the course, students had to correct faults in the subscriber provisioning section of the simulated IMS environment, check over the system architecture in terms of IP addresses and ports of the main IMS network components and finally check over the application configuration. Students were not informed initially about the locations of the faults. As we have seen, it has taken a full lab time to solve the exercise with medium level consultation i.e. every student needed some form of guidance to successfully solve the problem.

Basic provisioning of IMS. The sixth lab exercise has been an extension from the fifth exercise. When previously the whole environment was run on the local computer, then students have been asked to form teams of 2-4 people and distribute the IMS network functions over several computers in the lab. Students have had to design the layout of the solution, configure right addresses on the lab computers and run the test application.

In $2^{\text {nd }}$ year we had some extra time and tried to run an application test client on a Symbian mobile phone, which was connected to local wireless LAN in the lab network.

During this lab exercise, students are asked to find the most appropriate place for taking traffic trace (usually from the computer which simulates the CSCF function) and analyze the trace with Wireshark packet analyzer. Based on the material taught in previous seminars and labs, the students need to provide an explanation about the traffic flow and used SIP flows.

We find that these 6 laboratory exercises give sufficient overview and experience for students being able to independently continue the research and work in this area.

\section{Further development of course}

Since the course has been given together with partners from the Estonian Association of Information Technology and Telecommunications, the course is based on the industry interest and needs. The course has been a good example of merging the interests of several external partners from the industry and from the universities. Since the partner in technology has been Ericsson, the course has been focusing more on the Ericsson IMS solution. 
Due to the technology evolution and ongoing product development we see that the course needs to be updated in time as well. Technology providers have invested to the introduction of certain products, but from university point of view, the situation is changing too fast to be able to design a firm base for the course over the years. Also due to the economical situation in the market, other products and strategies may get higher priorities by technology providers and network operators when time passes.

Therefore from university point of view the course should be developed:

1. Keeping generic focus on VoIP systems and solutions and move the attention from IMS as a single solution. A good example has been IK2554 Practical Voice Over IP course in Swedish Royal University of Technology. IMS may be a smaller part in the course. This means that the course must take longer time in order to accommodate all the new topics and basics concepts. Another possibility is that some basics concepts are taught more in preceding courses in curricula.

2. In addition to lab exercises, students are asked to perform independent research works, which may result in analyses of an existing solution in the market or in a selfdeveloped tool, application or solution

3. Involve more alternatives and products from the same or several technology providers. For example Ericsson's Business Communication Suite solution to present the technology evaluation and trends in this technology sector from one providers point of view.

4. There is a threat that due to licensing policy the usage of Ericsson proprietary SDS development software may be not available for the course purposes. If the usage is discontinued, alternative platforms need to be found and the tasks related to SDS need to be replaced and redesigned.

\section{Conclusions}

The purpose of the course has been to give both practical and general knowledge about VoIP and IMS systems. The focus will be on the system architecture, communication models and underlying protocols and on the provided services.

Academies cooperation with industry partners is a good way to ensure that students get exposure to the technologies what their future employers have. Using industry specialists as teachers will ensure that a technology of interest will be taught by lecturers with practical experience on the field. Teachers must have presenting skills in order to be able to teach the subject. If these skills aren't sufficient then university must have a solution to ensure that these skills are improved or another teacher is used.

It is important to keep in mind that there is need for a backup plan if industry interest and support, due to the situation in economy and market, may be changed.

\section{Acknowledgements}

The authors would like to thank people from Ericsson Eesti Ltd., Elion Ltd., EMT Ltd. and from other industry partners who have helped to teach the course.

\section{References}

1. Brennenraedts, R., Bekkers, R., Verspagen, B. The different channels of university-industry knowledge transfer: Empirical evidence from biomedical engineering, working paper 06.04 // Eindhoven centre for Innovation Studies, 2006. $-25 \mathrm{p}$.

2. Jaccheri L., Morasca S. On the importance of dialogue with industry about software engineering education // Proceedings of the 2006 international workshop on Summit on software engineering education, 2006. - P. 5-8.

3. Krishnan P., Ross K., Pari-Salas P. Industry Academia Collaboration: An Experience Report at a Small University // Proceedings of 22nd Conference on Software Engineering Education and Training (CSEET'2009), 2009. - P. 117-121

\begin{abstract}
A. Ainomae, I. Rokk, E. Lossmann. Teaching of Telecommunication-Specific University Course in Cooperation with Partners from Industry // Electronics and Electrical Engineering. - Kaunas: Technologija, 2011. - No. 4(110). - P. $131-134$.

Modern information and telecommunication technology (ICT) is rapidly evolving in time and there is a constant need for specialists, who have good knowledge to meet the industry needs. One way to perform industry specific knowledge transfer form industry to academia is to involve partner's specialist in teaching the courses. The aim of this paper is to introduce an example of course setup in teaching VoIP and IMS technologies for ICT students. We analyze the opportunities and limitations seen in organizing and teaching this course based on our 3-year experience. We also give some suggestions for developing the course when industry interest and support, due to the situation in economy and market, may change in time. Bibl. 3 (in English; abstracts in English and Lithuanian).
\end{abstract}

\footnotetext{
A. Ainomae, I. Rokk, E. Lossmann. Specializuoto telekomunikaciju sistemų studiju kurso dėstymas bendradarbiaujant su pramonės sektoriumi // Elektronika ir elektrotechnika. - Kaunas: Technologija, 2011. - Nr. 4(110). - P. 131-134.

Šiuolaikinėje nuolat besivystančioje informacinių ir ryšių technologijų srityje reikalingi specialistai su rinkos poreiki atitinkančiomis žiniomis. Vienas iš būdų - įtraukti pramonès atstovus ị studijų procesą. Pateikiamas pavyzdys kaip buvo dėstomi VoIP ir IMS studijų kursai. Analizuojami pranašumai ir trūkumai, pastebėti per trejus metus. Pateikta pasiūlymų, kaip tobulinti kursą atsižvelgiant i besikeičiantị pramonės sektoriaus poreikị. Bibl. 5 (anglų kalba; santraukos anglų ir lietuvių k.).
} 